\title{
Women's Liberation in The Color Purple
}

\author{
Linzhi Shao \\ The Engineering \& Technical Institue of Chengu University of Technology, Leshan, Sichuan, \\ 614000
}

Keywords: lesbian, animism, woman-bounding

\begin{abstract}
In Alice Walker's The Color Purple, the protagonist Celie, one of the representatives of black woman goes through years of suffering and hardship under the oppression of black male v the white male and female. With the help of Shug, Sofia and Nettie, she tries her best to find her love and God. Her female awareness returns, her revolutionary occurs. She becomes a lesbian, leaves home, makes trousers and founds corporation. Finally, she is independent on sex, finance and her social status rises. Her liberation expresses Alice Walker's womanism fully, arises the masses to probe into the way of black women's liberation, and inspires black women to liberate themselves.
\end{abstract}

\section{Introduction}

Alice Walker is represented one of the most famous black women authors in American literary history sinc3e 1970s. She is also one of the founders of womanism. Though womanism is affected deeply by Black Nationalism and white women feminism, it is different from their basic theory. Black Nationalism centering on black men ignores the sex discrimination in the ethnic group and prettifies the relationship of the sexes, limits the black women's liberation, because the black women are also discriminated by black men and for black women, they suffer more bitterness.

Thus, according to the condition of black women, Alice Walker gives it an exact definition and the four key points that is anti-sexism, anti-racism, Africa-centrism, Humanism. "The Color Purple " published in 1982 expresses the womanism fully. That proves Walker's concept of women liberation is not narrow. Women's liberation can be equal to men's liberation, even human's liberation.

\section{Analysis of the protagonist's liberation}

During Celie's independence procedure, she gains love from lesbian, changes her view of God and finds spirit in animism resists the oppression with woman-bounding.

Love from lesbian. Generally speaking, lesbian is immoral and abnormal. But Celie gains love, one of the human being's basic spiritual props, from lesbian.

Surprisingly, Celie loves Shug, her husband's lover. How can Celie become to love Shug? From letters, it's natural and independent, which Celie does not have. She is full of individual characters and challenging spirit. She is very different from Celie and other traditional black women because she is free. Obviously, her activities threaten the male-dominant society. She can earn money by singing and choose her lover, completely independent of finance and sex. So her life style neglects the social doctrine of Christianity. And her father, a priest, drives her away. On Celie's mind, Shug is the dial embodiment of liberated black women and her idol. Moreover, no man loves her. Her stepfather rapes her, sells her children and force her to marry Mr.--. Mr.-marries her to take care of his children, farm and satisfy his sexual need. Obviously, Celie loves Shug because she did not gain love and respect as a woman from any males before, while Shug gives her everything she lacks: care, respect and love. Celie loses herself from men, but gains from woman.

Celie and Shug have a true practice. Firstly, sex education and sex intercourse. Shug teaches Celie to recognize their bodies, enjoy sexual love. Before this, Celie did not know anything about sex, even her body. She was very passive and disgusted during the sex intercourse, as Shug said, "You still a virgin."(1982:81) they make love. Factually, thesexual love comes from therespect to each other. Celie begins to realize that she is a person, not a tool. Furthermore, Shug helps her get 
letters from Nettie, hidden by Mr.--. And she persuades Mr.-not to beat Celie. When Celie does not believe God any more, she rescues her from credibility crisis and leads her animism. So, we can see it is Shug that inspires Celie to realize her worth on her own. With the help of her, Celie gets knowledge, friends, independence, money and time.

On the other hand, the love from lesbian also pushes Celie's practice and effort with the opposite sex forward. After she becomes active, independent, optimistic and wise during the communication with her husband, they finally become harmonious. "Mr.- seem to be the only one understand my feeling.”, she say. (1982:267)

Animism: love from religion. The term was first used by the English anthropologist Sir Edward B. Tylor. In" Primitive Culture"(1831)he described animism as "the general belief in spiritual beings," and called this a minimum definition of religion. Tylor held that animism, so defined, was the core of all religion, and that no primitive or crude society had been found which did not exhibit such a belief in spirits. The term "spirits" according to Tylor, applied not only to gods and divinities but also to souls of the living and the dead. Tylor held that belief in spirits arose because primitive man wondered about the phenomena of death, dreams, cataleptic and trance states, and other seeming mysteries for which they attempted to find an explanation. Wherever this belief in spirits existed, there was evidence of worship and ritual.

The term animism has also been used as a census category. Those people, particularly of Africa, Asia, and Pacific, who do not adhere to one of the universal religions, are classified as animists.

In the book, the first 55 letters are to God(God in Christianity, God the father, God the son and God the Holly Ghost, the Holly Trinity in the Christianity.), after that, 15 letters are to Nettie.

Firstly, Celie writes to God because of solitary. Her stepfather rapes her, threatens her, "you better not never tell nobody but God. It'd kill your mammy.”(1982:1) So, Celie becomes silent. Her mother curses her for her "big" without knowing the truth. And her sister Nettie is too young to understand what happened to Celie. There is no mother love, others' understanding. "Don't nobody come see us.”, she says. (1982:3). The strong feeling of solitary, shame and guilt pushes Celie to God, a fictitious mental world. Certainly, she could trust God, but God does not exist and cannot help her as well.

With the hope of God, Celie still struggles to live. She cannot be angry with her "daddy", for the doctrine of showing filial respect to parents; she has to bear husband's beating because she thinks, “this life soon be over, I say. Heaven last all ways.”(1982:44); when Sofia is maltreated by the whites, she imagines that "but I think bout angels, God coming down by chariot, swinging down real low and carrying ole Sofia home.”(1982:96). Innumerable hope, innumerable disappointment, God never appears to help her. When Shug asks her about God's appearance, she suddenly founds out "God is a white man" from the illustration in Bible. Finally, her imagination is shattered.

From Nettie's letters, Celie gets to know may things about African blacks lives, customer, traditional prescription, African animism as well. Factually, Nettie's journey to Africa reflexes the seeking-root movement in America in 1960s. African animism advocates that all the creature in the world has life, feeling and spirit. The "God" (God in animism, all the creatures contain God's spirit. Wherever this belief in spirits existed, there was evidence of worship and ritual.) should contain every creature and human being as well, not some people. So, god is everything. Everything that is or ever was or ever will be. God loves everything you love. Animism is diametrically opposed to Christianity. After Celie refuses to write to God, with the guide of Shug and Nettie, she tried her best to find God in life. God is not him or her, but it, as she wrote "To: Dear God. Dear Stars, dear trees, dear sky, dear peoples, Dear Everything. Dear God”(1982:292). She successfully finds out that she is same to the nature, everything is equal, everyone is equal. There is no discrimination of sex and ethnic, all the things in the world are harmonious.

\section{Woman-bounding}

The black woman is a "silent group" under the oppression of the black male , the white male and female. For them, their redemption must be pushed by their woman-bounding, their firm friendship. They share comforts and hardships, fight against the oppression together. So, Celie can gain love 
and power from the woman-bounding to get rid of humiliation, disappointment and oppression, and to start her life afresh.

Besides Shug, Sofia-Celie's daughter-in-law gives her encouragement by her resistance. Sofia, as all the black women, is strong and hard-working. However, she is never willing to be oppressed by anyone. Since her childhood, she and her sisters unit together to fight against her father and brothers, to fight against patriarchal domination. After she marries Harpo, she wants to be equal to him. But, Harpo wants to treat her as Mr.-treats Celie, beat her and conquer her. So, Sofia has to fight with him.

Once, Celie suggested Harpo beat Sofia for envy because Sofia could do what she could not do. She could beat her husband! But quickly, Celie felt regretful. They have a heart-to-heart exchange of views. "All my life I had to fight. I had to fight my daddy. I had to fight my brothers. I had to fight my cousins and my uncles. A girl child ain't safe in a family of men. But I never thought I'd have to fight in my own house." "To tell the truth you remind me of my mama. Se under my daddy thumb. Naw, she under my daddy foot. Anything he say, goes. She never say nothing back."(1982:43) To strengthen their friendship, they works on a "quilt”, Shug donates her old yellow dress for scrap. They call it "sister's choice”, representing woman-bounding.

When Sofia is in jail by beating Mayor--, Celie、Shug and Squeak plans to let Squeak, Harpo's lover, ask for her "uncle" - a worker in the jail. The result is a big shock to them. Squeak is raped by her "uncle", and they fail. What they can do it to look after Sofia's children when Sofia is in the jail. But this affair has a profound meaning that the black women unit to make their own effort to fight against the oppressing society.

However, the first person to teach Celie to resist is not Shug or Sofia, but Nettie. From Nettie, Celie begins to know the necessary of resistance "You go to fight, you got to fight."(1982:18) The poor Nettie is forced to leave Celie by Mr.--. Luckily, Nettie follows with Samuel to Africa to preach. Despite how the distance is long between them, they insist on writing to each other. The indomitable, true sister's love always encourages them to live firmly.

\section{Conclusion}

If American society is compared to a vertical line, the white man stand on the top of the line, black men lie in the middle, back women are at the bottom, oppressed by ethnic and sex. Though, the black women awakened and struggled, they can just be equal to the black men in the middle. We should notice and help this "minority" group, as Alice Walker says, "The creativity of black women is a measure of the health of human society."

\section{References}

[1] Alice Walker. The Color Purple [M].The Pocket Books. New York, U.S.A.1982.

[2] Carolyn Rhodes. Women Writers and The American Dream, Perspectives in American studies. [M]Shanghai Foreign Language Education Press. 1988:15.

[3] Mackinnon Catharine A. Feminism, Marxism, method and state: An agenda for theory [J]. Sign. 1982.

[4] Dina Benevol. Excel Studies in Literature: Alice Walker's The Color Purple [M]. Pascal Press. Glebe, NSW. 1994.

[5] Jingren Yang. The Color Purple (Chinese version) [M]. Beijing October Literature Press. 1987.

[6] Jingren Yang. “American Black Literature’s Breakthrough-Alice Walker's 'The Color Purple”, [J]. Foreign Literature Research. 1989.

[7] Yaoxin Chang. English And American Literature [M]. Nankai University Press. 1987.

[8] Dingbo Wu. An Outline Of American Literature [M]. Shanghai Foreign Language Education Press. 1998

[9] Mary Eagleton. Translated by Ming Hu, Laixia Chen and Shuming Lin. Literature Theory of Feminist [M]. Hunan Art Press. 1989. 
[10] Enming Wang. Research Of $20^{\text {th }}$ Century American Women [M]. Shanghai Foreign Language Education Press. 2002. 